\title{
A RADICAL CHANGE IN TRAFFIC LAW: EFFECTS ON FATALITIES IN THE CZECH REPUBLIC
}

\section{Josef Montag}

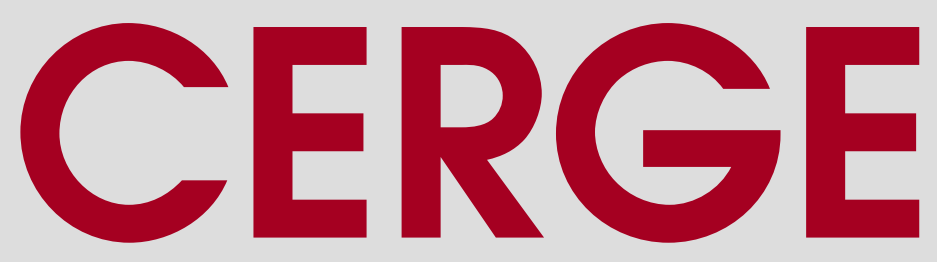




\section{Working Paper Series $\quad 484$ (ISSN 1211-3298)}

\section{A Radical Change in Traffic Law: Effects on Fatalities in the Czech Republic}

Josef Montag

CERGE-EI

Prague, March 2013 
ISBN 978-80-7343-288-1 (Univerzita Karlova. Centrum pro ekonomický výzkum a doktorské studium)

ISBN 978-80-7344-280-4 (Národohospodářský ústav AV ČR, v.v.i.) 


\title{
A Radical Change in Traffic Law: Effects on Fatalities in the Czech Republic*
}

\author{
Josef Montag ${ }^{\dagger}$ \\ Faculty of Law, Masaryk University and CERGE-EI ${ }^{\ddagger}$
}

February 2013

\begin{abstract}
I evaluate the effects of a new road traffic law in the Czech Republic that became effective on July 1, 2006. The law introduced tougher punishments through the introduction of a demerit point system and a manifold increase in fines, together with an augmented authority of traffic police. I find a sharp, 33.3 percent, decrease in accident-related fatalities during the first three post-reform months. This translates into 51 to 204 saved lives with 95 percent certainty. The decline was, however, temporary; estimates of the effects going beyond the first year are around zero. Unique data on traffic police activity reveal that police resources devoted to traffic law enforcement gradually declined and were shifted towards general law enforcement.
\end{abstract}

\begin{abstract}
Abstrakt
Studie hodnotí efekty Zákona o provozu na pozemních komunikacích v České republice, který vstoupil v platnost 1 . července 2006. Zákon přinesl tvrdší postihy řidičủ pomocí zavedení bodového systému a několikanásobného zvýšení pokut, spolu s posílením pravomocí policistů ve výkonu služby. V průběhu prvních tří měsíců platnosti zákona nastal prudký, 33,3 procentní, pokles počtu smrtelných zranění. To představuje 51 až 204 zachráněných životů s jistotou 95 procent. Pokles byl však krátkodobý a odhady efektů přesahujících první rok jsou kolem nuly. Unikátní data o aktivitě dopravní policie ukazují, že prostředky pro výkon služby postupně klesaly a byly více alokovány na obecné vynucování práva.
\end{abstract}

Keywords: Traffic law, traffic fatalities, policy evaluation, deterrence, enforcement.

JEL classification: I12, I18, K42, R41

*I would like to thank to Daniele Bondonio, Brendan Dooley, Libor Dušek, Kateřina Holíková, Michael Kohl, participants at the 2010 Conference on Empirical Legal Studies, the European Law \& Economics Association 2012 Annual Conference, and a workshop at the University of Economics, Prague for valuable comments and suggestions. I very much appreciate discussions with officers at the Czech Traffic Police Headquarters as well as their responses to data requests. The views expressed in this paper as well as any remaining mistakes and imperfections should be attributed only to the author. This research was funded by Czech Science Foundation grant no. $\mathrm{P} 402 / 12 / 2172$.

${ }^{\dagger}$ Email: josef.montag@cerge-ei.cz

${ }^{\ddagger}$ Center for Economic Research and Graduate Education-Economics Institute, a joint workplace of Charles University in Prague and the Academy of Sciences of the Czech Republic. Address: CERGE-EI, P.O. Box 882, Politických vězňů 7, Prague 1, 111 21, Czech Republic. 


\section{Introduction}

Each year, road traffic accidents (RTAs) result in as many as 50 million injuries and more than 1.2 million deaths, making it the ninth leading cause of death worldwideeffecting especially young people - and its importance is predicted to rise over the next two decades. Enacting comprehensive laws with appropriate penalties and ensuring necessary resources for enforcement are acknowledged as top instruments to improve road safety (World Health Organization 2009). However, proper policy choice requires that we understand how alternative measures perform when put in place and how they interact with other key variables. Exploiting past policy experiments is a natural way to improve our understanding of these phenomena.

This study evaluates the effects of a new road traffic law in the Czech Republic that became effective on July 1, 2006 (Parliamant of the Czech Republic 2005). It was aimed at improving road traffic safety through tougher sanctions for traffic offenses and the augmented authority of the police. Apart from a manifold increase in fines, the most important change introduced by the law was a demerit point system (DPS) under which an accumulation of points for traffic offenses leads to the suspension of driver's license. I overview the new road traffic law in detail in Section 2.

There are over a dozen studies investigating the effects of similar changes in traffic laws that also included a DPS recently adopted in other countries. ${ }^{1}$ I summarize these studies in Table A.1 in the Appendix. The common pattern of their findings is that the introduction of stricter traffic laws is followed by substantial decreases in RTA-related fatalities and other casualties, usually in the realm of 20 to 30 percent. $^{2}$ However, the effects going beyond the initial six months are ambiguous, as many of these studies are based on short-term data and there are contradictions among those that do look at long-run effects. For instance, one study for Ireland finds lasting

\footnotetext{
${ }^{1}$ Brazil did so in 1998, Ireland in 2002, Italy in 2003, Spain in 2006, and the United Arab Emirates in 2008.

${ }^{2}$ The study from the United Arab Emirates is an exception as it does not find any effects (Mehmood 2010).
} 
effects, but two others do not. ${ }^{3}$ Similarly in the case of Italy, where one research group finds lasting effects and three others do not. ${ }^{4}$ Some of the inconsistency in previous findings may be related to research design, which is always based on, a within-country, before-after comparison. One should therefore be careful before drawing strong inferences, as such results may be influenced by trends in the data and are fragile with respect to additional shocks, such as seasonality, weather, change in fuel prices, or business cycle.

This study evaluates the effects of the Czech road traffic law reform using a standard difference-in-differences set-up, whereas regions of neighboring countries (Austria and Germany) serve as a control group. In short, I find a very sharp but very short-lived reduction in fatalities. The paper adds three main contributions to the existing literature: a) a better identification strategy (previous evaluations of similar reforms in other countries used only a before-after comparison), b) an explanation of the shortlived nature of the effect by investigating how police enforcement activities responded to such a radical change in penalties, and c) the finding that police enforcement activities gradually declined after the reform, but the decline can hardly explain the quick rebound in the number of deaths following the initial drop.

I have collected monthly regional-level data on RTAs that occurred between January 2004 and December 2008 in the Czech Republic, Germany, and Austria and matched it with other socio-economic and transport-related statistics. Because data on accidents and injuries may suffer from reporting biases that are correlated with the new traffic law, I focus on fatalities. To the extent that the development of the variable of interest is similar across these countries, the control group allows estimating the counterfactual, i.e. the hypothetical scenario of what would have happened on Czech roads had the law not been enacted. Subtracting the observed values from the counterfactual then yields an estimate of the effect of the reform. The validity of the identifying assumptions is discussed in Section 3, but note here

\footnotetext{
${ }^{3}$ See Butler et al. 2006; Healy et al. 2004; Hussain et al. 2006.

${ }^{4}$ See Farchi et al. 2007; Instituto Nazionale di Statistica 2005; Benedettini and Nicita 2009; Zambon et al. 2007; Zambon et al. 2008.
} 
that there is strong positive correlation in RTA-related fatalities across the three countries, the three countries followed similar trends before the law was introduced, ${ }^{5}$ and there was no major change in Austrian or German traffic laws during the period under study.

Consistent with the experience from other countries I find a sharp - 40.5 log points - drop in fatalities during the first three months after the law became effective. This translates into 51 to 204 saved lives with 95 percent certainty. However, beyond the short-run impact, this paper extends the set of studies that do not find lasting effects of increased sanctions for traffic law violations. This result is robust to alternative specifications and controlling for GDP, car-population ratio, age of cars, and freight-transport vehicle-kilometers. Looking closer at the initial period, the effect was concentrated in July (the point estimate is -83.3 log points). An analysis of daily data corroborates these findings; moreover, there are no indices of pre-reform effects. The strongest effects are found in the weeks immediately following the enforceability of the reform.

So why were the effects short-lived? A possible concern is that the intensity of enforcement decayed in the aftermath of an increase in punishment. Intuitively, traffic law enforcement is costly and resources spent on it have alternative uses, be it within law enforcement or within the public sector in general. As the situation on the roads improves, alternatives may become more attractive.

I find evidence consistent with this reasoning using a unique monthly-regionallevel dataset with detailed information on traffic police activity during 2006 and 2007. Specifically, while the number of traffic policemen allocated to enforcement slightly increased, the total number of man-hours in enforcement decreased by some 22 percent across the two years. An even faster decay is seen in the number of hours of the use of speed guns by traffic police. On the other hand, the traffic police found more people at large, more stolen vehicles, as well as conducted more vehicle and person searches. The latter results, although rarely statistically significant, suggest

\footnotetext{
${ }^{5}$ See Figure 2 on page 14.
} 
that some reallocation of resources may also have taken place within traffic police itself. This may help explain the absence of longer-run effects. However, continuous changes in police activity do not explain the initial sharp drop in fatalities or the bouncing back. It is plausible that people simply overestimated the effects of the change in the rules on the effective punishments they faced. The salience of the change and lasting controversies in politics and media may have contributed to this.

The remainder of this paper is organized as follows: Section 2 details the 2006 traffic law reform in the Czech Republic. Section 3 describes the data and discuses the empirical strategy. Section 4 presents the main results. Section 5 analyzes the behavior of the traffic police around the reform and tries to figure out why the effects were shortlived. Section 6 then concludes.

\section{The Change in Czech Road Traffic Law}

The mechanics of the newly introduced DPS is straightforward and relatively strict. The law newly specifies the number of demerit points for each offense, from 1 , for minor ones, to 7 , for the most serious offenses. Drivers may receive points for different offenses at one time. A driver who accumulates 12 points has his license revoked for 12 months, automatically and immediately. ${ }^{6}$ The license is returned to the driver upon completion of a driving test and the driver continues to carry 12 points on his record. Four points are deleted from driver's record after each 12 months during which he does not receive any new points. ${ }^{7}$

The toughness of the Czech DPS can be highlighted by comparison with the Italian one, where drivers must only attend a driving course and pass a driving test

\footnotetext{
${ }^{6}$ The use the of masculine is justified by the fact that male drivers' behavior is more often associated with negative externalities than females drivers', both in conventional wisdom as well as empirically (Levitt and Porter 2001; Chipman and Morgan 1975; Redelmeier, Tibshirani, and Evans 2003).

${ }^{7}$ Before this change, a driver's license could have been revoked only upon conviction of a specific offense or crime. It can still be revoked in such instances, regardless of the number of accumulated points and, in addition, the driver receives demerit points according to the offense he committed. If at the same time the driver happens to exceed his 12-point limit, the 12-month period begins only after the main revocation period is completed.
} 
Figure 1: Average fine for speeding in 2006 and 2007

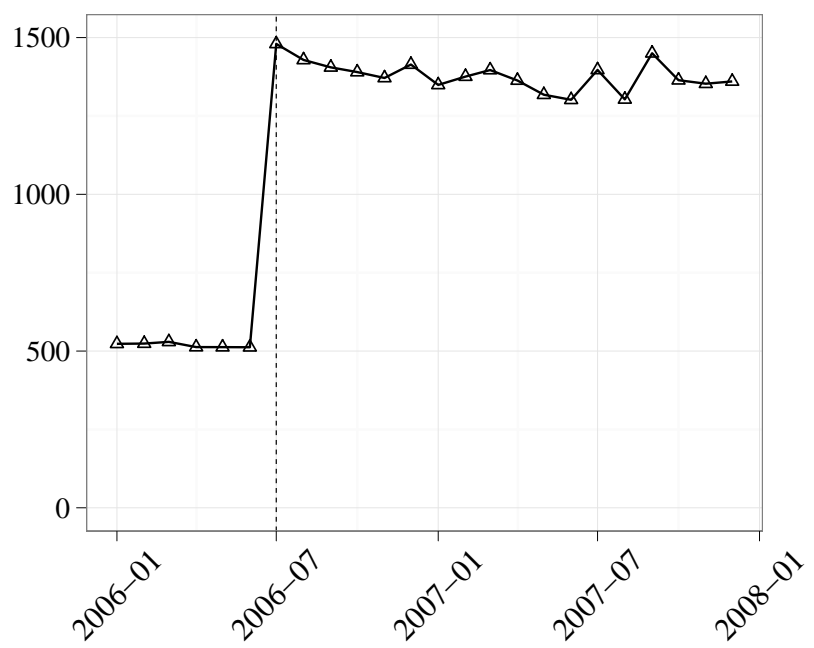

within 30 days after exhausting their point endowment; they also get all their points back. $^{8}$ The license is only suspended if they fail to pass the test. ${ }^{9}$

The introduction of DPS was complemented by a general increase in fines and police officers' discretion as to the actual amount of fine was removed in most cases. Maximum fines for offenses that can be solved on the spot, if driver accepts the ticket, were mostly raised twofold, but fines for speeding were tripled, as illustrated in Figure $1{ }^{10}$ Similarly, fines were increased for more serious offenses that are dealt with by the municipal office. Driving under the heavy influence of alcohol became a jailable crime.

Other key changes the law introduced are summarized in Table A.2. Notably, the authority of the police was elevated substantially as the law sought to strengthen enforcement. Police regained the capacity to retain a driver's license on the spot and if a driver refuses an alcohol test, the police can seize his vehicle or prevent the driver from continuing. Municipal police were newly awarded the authority to stop vehicles, impose fines, and give alcohol tests. Radar detectors became illegal, while child seats and all-day lighting were made compulsory. Vehicle owners became

\footnotetext{
${ }^{8}$ Drivers in Italy have an endowment of 20 points and they lose points upon committing an offense.

${ }^{9}$ Basili et al. (2012) indeed find that drivers tend to commit more offenses after zeroing out and reloading their points.

${ }^{10}$ Median wage before taxes was 19,500 Czech Crowns (CZK) in 2006. One Euro equals approximately 25 CZK, one U.S. Dollar is about 19 CZK.
} 
obliged to provide information on the identity of the driver in order to make the offenses documented by static speed cameras better enforceable.

All in all, the law can be plausibly described as having substantially altered the formal rules that govern road traffic in the Czech Republic. The rules of the newly introduced demerit point system are strict - only two or three offenses can add up to 12 points, resulting in an immediate year-long license suspension-and this was accompanied by a general increase in fines and augmented police authority.

\section{Data and Empirical Strategy}

\subsection{Descriptive Statistics and Measurement Issues}

\subsubsection{Data Collection}

The main data set analyzed in this paper consists of monthly regional-level data on RTA-related casualties that occurred between January 2004 and December 2008 in the Czech Republic, Germany, and Austria, obtained upon specific requests from the Czech Traffic Police Headquarters and statistical offices of Germany and Austria. ${ }^{11}$ I then merged this data with yearly regional-level data on the population and number of cars from Eurostat and yearly country-level data on transport and economic statistics from the same source. In addition, I received daily data on fatalities in Austria and the Czech Republic covering 2005 to 2008. Finally, from the Czech Traffic Police Headquarters I have obtained detailed information on traffic police activity, such as man-hours, hours of use of speed guns, the number of cleared offenses, and the amount of collected fines. From this information I was able to parse a regional-level dataset covering monthly police activity in the Czech Republic in 2006 and $2007 .{ }^{12}$

\footnotetext{
${ }^{11}$ I have also made data requests to the Polish, Slovakian, and Hungarian statistical offices, however I was not successful in those cases.

${ }^{12}$ The data on traffic police activity is described and analyzed in Section 5.
} 


\subsubsection{Fatalities and Injuries}

Table 1 summarizes the data on RTA-related casualties in Austria, the Czech Republic, and Germany (split by former East and West) before and after July 1, 2006. Looking at the levels of fatalities, the Czech Republic had the highest rate per million inhabitants as well as per million cars in both periods. From the first column it is also apparent that the two neighboring countries experienced a decline in the number of RTA-related fatalities, which was comparable - with the exception of the former East German regions - to the decline in fatalities in the Czech Republic. However, the number of cars cruising Czech roads grew 3 to 4 times faster compared to Austria and Germany, as seen in the last column. If the number of cars reflects the intensity of traffic in a country, the rate of fatalities per car is more likely to capture the safety situation on the roads. This adjustment leads to a 14 percent decline in fatalities in the Czech Republic and former East Germany compared to 8 and 9 percent decreases in Austria and Germany, respectively.

The picture is quite different when we look at injuries, however. First, the Czech Republic exhibits the lowest injury rates for both serious and slight injuries. The difference is substantial: Czech rates of RTA-related slight and serious injuries per million inhabitants are about 50 percent lower compared to Austria and Germany, while the number of injuries per million cars is still about $1 / 3$ smaller. This looks to be somewhat at odds with the larger fatality rates in the Czech Republic relative to its neighbors. Regarding changes over time, we see that - despite the declines in fatalities - injuries per million inhabitants in Austria and Germany remained relatively stable; only serious injuries declined by about 4 percent in former East Germany. Similarly, injuries per million cars declined rather modestly in these two countries. In all cases, the decline in injuries is much smaller than the decline in fatalities. However in the case of the Czech Republic, the decline in injuries always exceeds the decline in fatalities, most notably for the seriously injured.

There are two sources of concerns about the comparability of police data on injuries across the three countries as well as over time. First, police resources are 
Table 1: Summary Statistics of RTA Related Casualties (July 2004-June 2008)

\begin{tabular}{|c|c|c|c|c|c|c|c|c|}
\hline \multirow[b]{2}{*}{ Country } & \multirow[b]{2}{*}{ Period } & \multicolumn{3}{|c|}{ Per $10^{6}$ Inhabitants } & \multicolumn{3}{|c|}{ Per $10^{6}$ Cars } & \multirow[b]{2}{*}{$\begin{array}{l}\text { Cars per } \\
\text { Inhabitant }\end{array}$} \\
\hline & & Fatalities & $\begin{array}{l}\text { Serious } \\
\text { Injuries }\end{array}$ & $\begin{array}{l}\text { Slight } \\
\text { Injuries }\end{array}$ & Fatalities & $\begin{array}{l}\text { Serious } \\
\text { Injuries }\end{array}$ & $\begin{array}{l}\text { Slight } \\
\text { Injuries }\end{array}$ & \\
\hline \multicolumn{9}{|c|}{ A: Totals by period before and after July 1, 2006} \\
\hline \multirow{2}{*}{ Czech R. } & Before & 221.4 & 888.8 & 5451.2 & 572.5 & 2298.3 & 14095.7 & 0.39 \\
\hline & After & 202.8 & 760.0 & 4824.4 & 489.6 & 1834.7 & 11646.9 & 0.41 \\
\hline \multirow{2}{*}{ Austria } & Before & 188.9 & 1708.2 & 9793.6 & 372.9 & 3371.4 & 19329.7 & 0.51 \\
\hline & After & 175.0 & 1718.5 & 9670.4 & 342.0 & 3359.5 & 18904.3 & 0.51 \\
\hline \multirow{2}{*}{ W. Germany } & Before & 125.4 & 1805.0 & 8759.7 & 222.6 & 3202.4 & 15541.1 & 0.56 \\
\hline & After & 117.0 & 1777.1 & 8821.1 & 202.3 & 3072.8 & 15252.8 & 0.58 \\
\hline \multirow{2}{*}{ E. Germany } & Before & 153.3 & 2116.4 & 7739.2 & 305.3 & 4215.1 & 15414.0 & 0.50 \\
\hline & After & 135.6 & 2036.2 & 7855.2 & 263.1 & 3949.3 & 15235.4 & 0.52 \\
\hline \multicolumn{9}{|c|}{ B: Proportional change between before and after periods } \\
\hline Czech R. & - & -0.08 & -0.15 & -0.12 & -0.15 & -0.20 & -0.17 & 0.071 \\
\hline Austria & - & -0.07 & 0.01 & -0.01 & -0.08 & 0.00 & -0.02 & 0.010 \\
\hline W. Germany & - & -0.07 & -0.02 & 0.01 & -0.09 & -0.04 & -0.02 & 0.026 \\
\hline E. Germany & - & -0.12 & -0.04 & 0.02 & -0.14 & -0.06 & -0.01 & 0.027 \\
\hline
\end{tabular}

Notes: The first and last 6 months were dropped to make the within-country comparison free of seasonal effects. The number of fatalities for the Czech Republic refer to people who died within 24 hours of an accident, for Austria and Germany to people who died within 30 days of the accident. The estimate of the number of cars in Germany was revised downward in 2007; since this variable was developing virtually linearly, I replaced the revised numbers with the linear extrapolation.

Sources: Headquarters of the Police of the Czech Republic, Statistics Austria, Federal Statistical Office Germany, and Eurostat.

likely to differ across these countries and drivers have incentives to avoid calling the police to an accident involving injury in order to sidestep additional punishment. In marginal cases, drivers may also strike a deal and settle the damages privately. As a consequence, there may be differences in the share of accidents the police never learn about.

Second and more importantly, it is quite likely that these reporting issues have been aggravated by the changes in the Czech road traffic law because the incentives not to call the police strengthen as the punishments became harsher. In addition, the law made such strategies cheaper, because it raised the minimum damage below which the police do not have to be notified about an accident from CZK 20,000 to CZK $50,000{ }^{13}$ Both factors are likely to increase the pool of accidents and injuries unnoticed by the police. At the same time, the police or the doctors may have an

\footnotetext{
${ }^{13}$ Although this change was motivated by the need to free police resources from dealing with minor accidents, it may also work against the general philosophy of the new law, because offenders who cause minor accidents go unpunished. I am grateful to Lt. Col. Josef Tesařík for pointing this out to me. Another ramification for our study is that police data on accidents are not suitable for the evaluation.
} 
incentive not to record some injuries, or classify injuries on the margin as minor, if the related punishment would now seem inappropriate. The importance of these factors possibly increases with the corruptibility of the police.

This scenario seems to fit the development of RTA-related injuries in the Czech Republic and the inconsistency in dynamics when compared with Austria and Germany. It is also consistent with the larger decline in serious injuries compared to slight injuries (see Table 1) as some injuries on the margin may be more often classified as slight and some slight injuries get concealed. Since there are no marginal fatalities, the effect of classification should be stronger in the case of serious injuries than slight injuries.

Such reporting issues are unlikely to play a role in the case of fatalities. First, it is hard to conceal an accident involving a fatality from the police. Second, as just noted, there are no marginal fatalities that could be labeled otherwise. Third, any private settlement is hardly feasible. ${ }^{14}$

To probe things further, I compared the police data with yearly data on road traffic fatalities and injuries from the Institute of Health Information and Statistics of the Czech Republic (IHIS). With the exception of Prague, the IHIS data on fatalities were very similar to the police data. ${ }^{15}$ The comparison looks different for injuries. While the police observed a sharp, 14.6 percent, decline in RTA-related injuries in 2006, the IHIS figure remained essentially unaltered (it was slightly higher in fact). The following year the police figure rose by about 4 percent while the IHIS figure was about 11 percent down from the previous year. ${ }^{16}$ These comparisons support the claim that the police data on RTA-related injuries are problematic. For these reasons I focus solely on data on fatalities in what follows.

\footnotetext{
${ }^{14}$ It is possible that some RTA-related fatalities may be labeled as not related to RTA. I consider this possible effect of the law unimportant.

${ }^{15}$ The proportional differences between the IHIS and the police statistics each year were -0.048 , $-0.019,0.023,0.021$, and 0.085 in 2004 to 2008. If the doctors' data were correct, the police data slightly overstate the number of fatalities in the first two years in our main sample and understate it from 2006 onwards, notably in 2006, biasing results in this study in favor of finding negative effects of the change in law on fatalities. Nevertheless figures from both sources are comparable both in level as well as their behavior over time.

${ }^{16}$ The proportional differences between the IHIS and the police statistics each year were, 0.13 , $0.24,0.44,0.24$, and 0.18 in 2004 to 2008 .
} 
This analysis also resulted in dropping Prague from the analysis. Prague constituted an outlier with very different behavior from the rest of the country. In addition, there were discrepancies between the police data and data from the Institute of Health Information and Statistics.

\subsubsection{Transport Statistics and the Economy}

Table A.3 presents a summary of the available transport statistics and GDP from Eurostat. Compared to Austria, the kilometers driven by Czech cars increased substantially. At the same time, the average number of passengers per car was decreasing, in fact canceling out the increase in kilometers driven and resulting in a slight decrease in passenger-km per car in the Czech Republic over the period under study.

The high intensity of transport traffic after the Czech Republic became a member of the European Union in 2004 is often mentioned as potentially elevating the riskiness of Czech roads. During the years 2004-2008, the volume of freight transport (including empty truck movements) in the Czech Republic increased substantially, but it also did in Germany.

Finally, the second half of the 2000s was an era of rapid economic growth in the Czech Republic - real GDP per capita measured in 2005 Euros increased by 32 percent. ${ }^{17}$ The expectation of the effect of GDP growth on RTA-related fatalities per car is ambiguous; in the short run, one would expect increased traffic to dominate, implying a positive correlation between GDP and fatalities. In the medium and longer perspective, people may acquire better cars as their incomes increase, families may buy a second car, and also public infrastructure may improve, resulting in a negative effect on fatalities.

\footnotetext{
${ }^{17}$ This partially reflects the strengthening of the Czech Crown throughout the period, however the growth in Crowns would still be at 20 percent.
} 


\subsection{Empirical Strategy}

\subsubsection{The Outcome of Interest}

As we saw in Table 1, the number of cars grew much faster in the Czech Republic compared to Austria and Germany. Assuming cars are bought to be driven, the number of cars should be positively related to the total number of kilometers driven in a country. This suggests that the intensity of road traffic was changing and grew faster in the Czech Republic relative to the two neighbors. Under such circumstances, it is not feasible to take the number of accidents or fatalities in a country as a measure of traffic safety, as risk exposure changed. ${ }^{18}$ I therefore use the number of fatalities per one million cars as a measure of road safety and the variable of interest.

An issue with using the number of cars to adjust for changes in traffic intensity can be that the number of kilometers per car or the average number of passengers sitting in a car may change. Both variables are very likely positively related to fatalities. ${ }^{19}$ According to the statistics from Eurostat (Table A.3), passenger-kilometers per car declined by almost 5 percent in the Czech Republic (kilometers driven grew by 20 percent, but the decrease in the number of passengers per car offset it) and did not change in Austria between 2004 and 2008. ${ }^{20}$ This indicates that using the number of cars as a measure of exposure to the risk of dying in a traffic accident is biased upwards in the case of the Czech Republic after 2006; this implies a downward bias of estimates of the effect of the legal change on fatalities, i.e. making it more likely that a-long run-negative effect of the law on fatalities will be found. ${ }^{21}$

\footnotetext{
${ }^{18}$ For instance, if people decided to double the number of kilometers driven per day, it would not be surprising to see an increase in the number of accidents, while it would be difficult to make any statement as to the implied change in traffic safety.

${ }^{19}$ Other things remaining equal, more kilometers driven imply more opportunities for accidents to happen, while more passengers in a car imply more injuries or fatalities in any given accident.

${ }^{20}$ Data for Germany is not available.

${ }^{21}$ This reasoning abstracts from the indirect effect of a higher number of car-kilometers on the probability of an accident working simply through more cars meeting on the road. Also, new drivers may be more likely to cause an accident, a factor possibly at work in the Czech Republic with its rapidly growing stock of cars. (On the other hand new cars are safer.) I suggest these factors are likely to be dominated by the mechanics of kilometers driven and passengers sitting in a car.
} 


\subsubsection{Empirical Model}

This paper employs a difference-in-differences (DD) estimator using neighboring countries as a control group. Specifically, denote $y$ the outcome of interest, then a DD regression can be written as

$$
y_{r t}=\rho_{r}+\boldsymbol{\tau}_{\boldsymbol{t}}+\boldsymbol{\beta}^{\prime} C_{c} \boldsymbol{T}_{\boldsymbol{t}}+\boldsymbol{\gamma}^{\prime} \boldsymbol{x}_{r t}+\epsilon_{r t}
$$

where $c$ denotes a country; $r$ denotes a region; $t$ denotes the date; $\rho_{r}$ is region $r$ 's fixed effect; $\boldsymbol{\tau}_{\boldsymbol{t}}$ is a full set of time effects picking up common trends, shocks, and seasonal regularities; $C_{c}$ is a dummy for the Czech Republic; $\boldsymbol{T}_{\boldsymbol{t}}$ is a vector of time effects; $\boldsymbol{x}_{\boldsymbol{r} \boldsymbol{t}}$ is a vector of additional controls; and $\epsilon_{r t}$ is the residual. Specifically, $\boldsymbol{T}_{\boldsymbol{t}}$ consists of dummies for four post-reform quarters and a dummy for the fifth to tenth quarter after the reform. The parameter of interest is the vector $\boldsymbol{\beta}$, which consists of five coefficients capturing the effects of the traffic law reform on fatalities over time.

The well-known advantage of this estimator is that it helps with controlling for any unobserved shocks, as long as they affect the treated as well as the control group. This facilitates more robust inference about the casual effect of the change in road traffic law on RTA-related casualties relative to before-after comparisons employed in existing studies. The identifying assumptions of the DD estimator are common trends between the treated and the control group as well as the absence of any unobserved shock specific only to the control countries or to the treated country. In other words, the DD estimator requires that after controlling for relevant differences between the control and treated groups, the only systematic difference between the two is the presence of the treatment.

\subsubsection{Validity of Assumptions}

There are good reasons to expect that factors generating shocks to RTA-related fatalities are shared among the Czech Republic, Austria, and Germany, so the neighboring countries offer themselves as natural control group. Specifically, common 
Figure 2: Fatalities per $10^{6}$ Cars (2004-2008)

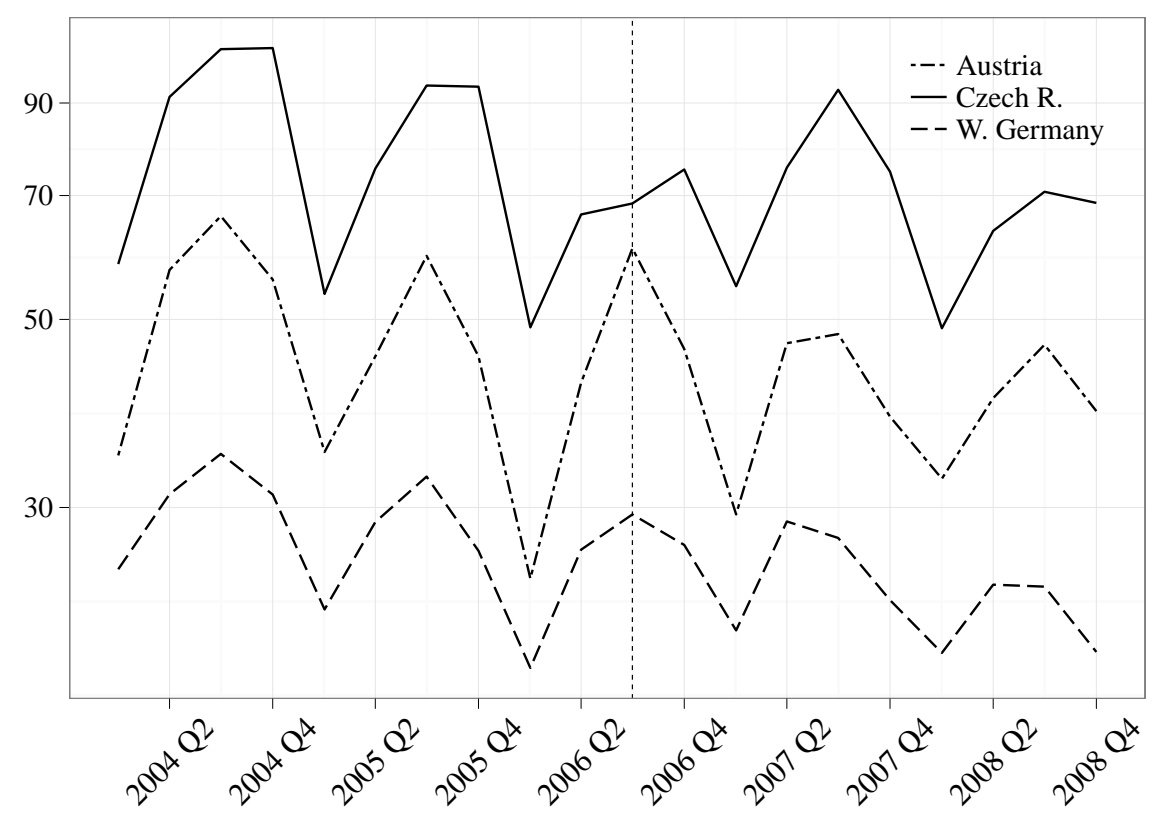

borders and the relatively small size of the Czech Republic make it likely that weather conditions will affect these three countries similarly. Moreover, the Czech economy is export-oriented - exports represented over 60 percent of its GDP in 2006, while Germany is the main trading partner with a $1 / 3$ share of Czech exports. Thus, economic shocks are correlated across these three countries. Finally, there was no substantial policy change in either control country. ${ }^{22}$

Since our data span 30 months before the traffic law reform in the Czech Republic, we can use this information to probe the identifying assumptions of regression (1). Figure 2 provides visual evidence suggesting similar log-linear trends in fatalities per car before 2006 as well as a similarity of seasonal regularities across the Czech Republic, Austria, and former West Germany. ${ }^{23}$ Pearson's correlation coefficients

\footnotetext{
${ }^{22}$ I have sent inquiries about changes in traffic law or policies between 2004 and 2008 to the ministries of transport of Austria and Germany. A detailed answer came from the Austrian ministry, listing all changes that occurred in that period. These were limited provisions such as an obligation to carry a reflective vest (2005) or the obligatory use of winter tires (2006, the only change in that year) or an increase of the fine for using a cell phone in 2008. I did not receive any response from the German ministry, however researching publicly available resources did not result in finding any substantial law or policy change in Germany between 2004 and 2008.

${ }^{23}$ Because the regions of former East Germany exhibited a very different trend compared to the rest of the countries in the region - namely, fatalities were falling much faster in Eastern Germany than elsewhere-I drop them from the data. As discussed below, I also studied yearly regional-level data from Eurostat, which are available for all neighboring countries. The uniqueness of former East Germany applies not only with respect to the three countries present in our main data, but to two other neighboring countries, Poland and Slovakia, as well as to Hungary.
} 
of log monthly fatalities per million cars between the Czech Republic and either control country from January 2004 until June 2006 are above 0.7 and are statistically significant at any conceivable level.

To assess the pre-reform similarity between the Czech Republic and Austria and Germany more formally, I construct a Chow test of systematic deviations of fatalities in the Czech Republic from the control group. Specifically, I take a pre-July 2006 subset of the data and run a regression of log-fatalities per car on regional fixed effects, a full set of time effects (i.e. year-month dummies), and a set of interactions between time effects and a dummy for the Czech Republic. Time effects in this regression pick up trends and shocks common to all three countries, while the interactions capture deviations specific to the Czech Republic. The test of the hypothesis that all coefficients on the interaction terms are equal to zero produces $F(29,754)=0.71$, in other words, there is no evidence that fatalities before July 2006 behaved differently in the Czech Republic compared to Austria and Germany.

To double-check this contention, I run the same test using the Eurostat yearly regional-level data on fatalities between 1999 and 2005 for all neighboring countries, replacing year-month dummies with year dummies. This data include Austria, the Czech Republic, former West Germany, Poland, and Slovakia. ${ }^{24}$ Testing the hypothesis that year effects for the Czech Republic are equal to zero results in $F(6,228)=0.889$. Running the same test on data for that only include the Czech Republic, former West Germany, and Austria produces $F(6,156)=0.7947$.

These findings suggest strong similarities in the development of fatalities between the Czech Republic and Austria and Germany before July 2006. That in turn justifies the use of the difference-in-differences estimation strategy.

\footnotetext{
${ }^{24}$ While data are available from 1996, there are frequent revisions, especially in statistics on number of cars, making the earlier data less reliable. Also, the Czech Republic experienced a financial crisis in 1997, recovering in 1999. I therefore drop observations before 1999. As discussed in Footnote 23, I excluded the regions of former East Germany, since it exhibits a very different trend from all the other countries.
} 


\subsubsection{Meaning of Estimates}

In our case, the coefficients $\boldsymbol{\beta}$ from regression 1 represent time-varying treatment effects on the treated, as the policy change was designed and introduced by the Czech Republic itself, unlike in a random assignment. Thus, $\beta$ s evaluate the effects of the legal reform in the Czech Republic and cannot be thought as an estimate of the effect in an experimental sense. ${ }^{25}$ There can also be a potential endogeneity bias in the sense that the timing of the reform may not be random. A recent experience of an unusually high number of serious accidents may make it more likely that a policy change will be put in place. This would constitute a bias in the direction of finding an effect due to the regression fallacy, as a random spike in fatalities is likely to be followed by values closer to the average (Friedman 1992). However, the length of the legislative process and the time span between the passage of a law and the date from which it is effective -9 months in the case we study - make this factor unlikely to drive our results in an important way. ${ }^{26}$ Importantly, these biases work against the finding of no significant effect of the reform and therefore make the conclusions of this paper conservative.

The last potential bias is related to the pre-reform effects of the new road traffic law. Everyone was long aware that the change in the road traffic law was coming soon and this may have affected pre-reform outcomes, in fact generating some effects of the reform before it actually took place. ${ }^{27}$ This would be likely to create a downward bias in $\beta \mathrm{s}$ as the level of fatalities in the treated country prior the reform would be lower. The potential pre-reform decrease should be attributed to the reform itself, since it would have not occurred otherwise. This bias is likely to be less dramatic

\footnotetext{
${ }^{25}$ This self-selection should make it more likely for the treatment to work compared to a randomly assigned treatment. Also, as apparent from Table 1, Czech roads were more dangerous than German and Austrian roads, the likely benchmarks, and there was no sign of convergence in fatalities per capita before 2006. Thus, some reform might have been be thought necessary.

${ }^{26}$ The traffic law was passed on September 21, 2005 and became enforceable on July 1, 2006.

${ }^{27}$ For instance, police may have acquired new assets or invested in new technologies before the reform, or they may have strategically increased their effort prior the reform, or engaged in saber rattling in the media. Also, drivers may have begun to drive more carefully or pay more attention to road signs. They may also have expected the police to increase their effort around the introduction of the reform.
} 
the longer the data for the pre-reform period. There are also simple strategies to address this: one can include a dummy for some part of the period prior the reform and interact it with the dummies of the treated group. I also inspect the daily data on RTA-related fatalities and find no appreciable pre-reform effects.

\section{Results}

\subsection{Main Results}

The main set of ordinary least squares estimates of the effects of the new Czech road traffic law on fatalities using regression (1) are reported in Table $2 .{ }^{28}$ Specification (1) (I will refer to it as the "base result") shows that the immediate effects of the law were substantial, but shortlived. The point estimate for the first postreform quarter suggests that fatalities in the Czech Republic declined by one third $\left(=\left[e^{-0.406}-1\right] \times 100\right) .{ }^{29}$ However, the estimated effects during the second, third, and fourth post-reform quarters are comparatively smaller and never statistically significant, individually or jointly. ${ }^{30}$ The estimate of the last coefficient suggests that the long-run effects, that is, beyond the first year after the traffic law reform, were essentially zero.

The rest of Table 2 reports alternative specifications to check the robustness of this base result. In specification (2) I drop the distant regions of Austria and Germany. The idea is that neighboring regions may be more alike in their behavior over time as well as affected by similar factors. This results in somewhat smaller and shorter estimated effects, yet the big picture is not altered. Then, in specification (3), I replace the outcome variable, log of fatalities per car, by the log of fatalities per passenger-kilometer, which is a preferred measure of traffic intensity. Because

\footnotetext{
${ }^{28}$ Because there are some month-region observations where no accidents occurred and I code them as zero, OLS coefficients are biased due to censoring. I rerun the analysis using a Tobit model instead. The differences in coefficients were barely discernible. Dropping those observations did not change the results, either. I therefore prefer to report OLS results.

${ }^{29}$ Most of this decline was actually concentrated in July, the first month the law was in place, when fatalities fell by 55 percent. I do not report this regression to save space.

${ }^{30}$ Testing whether these three interactions are jointly equal to zero yields $F(3,1473)=0.45$.
} 
Table 2: Effects of the New Traffic Law on Fatalities

\begin{tabular}{lcccc}
\hline & $(1)$ & $(2)$ & $(3)$ & $(4)$ \\
\hline $1^{\text {st }}$ quarter post-reform & $-.406^{*}$ & $-.310^{*}$ & $-.424^{*}$ & $-.406^{*}$ \\
& $(.108)$ & $(.099)$ & $(.153)$ & $(.106)$ \\
$2^{\text {nd }}$ quarter post-reform & -.102 & -.005 & -.145 & -.101 \\
& $(.129)$ & $(.134)$ & $(.153)$ & $(.126)$ \\
$3^{\text {rd }}$ quarter post-reform & -.143 & -.132 & .103 & -.142 \\
& $(.147)$ & $(.160)$ & $(.235)$ & $(.143)$ \\
$4^{\text {th }}$ quarter post-reform & -.073 & .057 & .054 & -.072 \\
& $(.104)$ & $(.148)$ & $(.150)$ & $(.106)$ \\
$5^{\text {th }}-10^{\text {th }}$ quarters post-reform & -.004 & .031 & .007 & -.004 \\
& $(.058)$ & $(.055)$ & $(.081)$ & $(.055)$ \\
$1^{\text {st }}$ quarter pre-reform & & & & -.015 \\
& & & & $.130)$ \\
$2^{\text {nd }}$ quarter pre-reform & & & .023 \\
& .600 & .549 & .337 & .600 \\
\hline adj. $R^{2}$ & 1560 & 840 & 960 & 1560 \\
$N$
\end{tabular}

Notes: The outcome variable in specifications (1), (2), and (4) is the monthly log of fatalities per $10^{6}$ cars in Austrian, Czech, and German regions between 2004 and 2008. Specification (2) is run on a sample without the distant regions of Austria and Germany. The outcome variable in specification (3) is log fatalities per $10^{11}$ passenger-kilometers - data available only for Austria and the Czech Republic. All specifications include region dummies and an unrestricted set of month $\times$ year effects. Huber-White standard errors clustered on regions are in parentheses: * $p<0.01$.

Sources: Headquarters of the Police of the Czech Republic, Statistics Austria, Federal Statistical Office Germany, and Eurostat.

the data on passenger-kilometers are not available for Germany, the data includes only the Czech Republic and Austria. The main findings are again corroborated, although the initial effects seem to decay even faster - everything beyond the initial 6 months has positive point estimates. Lastly, to check for potential pre-reform effects, I added dummies for two pre-reform quarters in specification (4). Both pre-reform coefficients are close to zero and the estimated effects are therefore the same as in specification (1). ${ }^{31}$ To summarize, these findings provide strong evidence of substantial immediate effects of the new road traffic law on fatalities in the Czech Republic, but not much is apparent beyond that.

Table 3 probes our base results with additional control variables. I first include GDP per capita, which grew faster in the Czech Republic compared to Austria and Germany, as seen in the last column of Table A.3. Then I plug in the number of

\footnotetext{
${ }^{31}$ I also estimated a model with the interaction of a dummy for the first quarters with a dummy for the Czech Republic, to control for different seasonal patterns. The results did not appreciably differ.
} 
Table 3: Effects of the New Traffic Law: Controlling for GDP and Transport Variables

\begin{tabular}{|c|c|c|c|c|c|c|}
\hline & (1) & $(2)$ & $(3)$ & (4) & $(5)$ & (6) \\
\hline $1^{\text {st }}$ quarter post-reform & $\begin{array}{r}-.434^{*} \\
(.128)\end{array}$ & $\begin{array}{r}-.404^{*} \\
(.108)\end{array}$ & $\begin{array}{r}-.355^{*} \\
(.108)\end{array}$ & $\begin{array}{r}-.408^{*} \\
(.109)\end{array}$ & $\begin{array}{r}-.416^{*} \\
(.127)\end{array}$ & $\begin{array}{r}-.365^{*} \\
(.132)\end{array}$ \\
\hline $2^{\text {nd }}$ quarter post-reform & $\begin{array}{c}-.131 \\
(.140)\end{array}$ & $\begin{array}{c}-.083 \\
(.151)\end{array}$ & $\begin{array}{c}-.050 \\
(.125)\end{array}$ & $\begin{array}{c}-.103 \\
(.130)\end{array}$ & $\begin{array}{c}-.113 \\
(.155)\end{array}$ & $\begin{array}{r}-.049 \\
(.166)\end{array}$ \\
\hline $3^{\text {rd }}$ quarter post-reform & $\begin{array}{c}-.172 \\
(.150)\end{array}$ & $\begin{array}{c}-.139 \\
(.147)\end{array}$ & $\begin{array}{c}-.028 \\
(.150)\end{array}$ & $\begin{array}{c}-.210 \\
(.174)\end{array}$ & $\begin{array}{c}-.102 \\
(.158)\end{array}$ & $\begin{array}{c}-.138 \\
(.190)\end{array}$ \\
\hline $4^{\text {th }}$ quarter post-reform & $\begin{array}{c}-.111 \\
(.120)\end{array}$ & $\begin{array}{c}-.059 \\
(.109)\end{array}$ & $\begin{array}{c}.043 \\
(.099)\end{array}$ & $\begin{array}{c}-.140 \\
(.147)\end{array}$ & $\begin{array}{c}-.060 \\
(.145)\end{array}$ & $\begin{array}{c}.032 \\
(.154)\end{array}$ \\
\hline $5^{\text {th }}-10^{\text {th }}$ quarters post-reform & $\begin{array}{r}-.057 \\
(.085)\end{array}$ & $\begin{array}{c}.001 \\
(.056)\end{array}$ & $\begin{array}{c}.134 \\
(.098)\end{array}$ & $\begin{array}{c}-.081 \\
(.133)\end{array}$ & $\begin{array}{c}-.008 \\
(.137)\end{array}$ & $\begin{array}{r}-.027 \\
(.139)\end{array}$ \\
\hline Log GDP per capita & $\begin{array}{l}.261 \\
(.374)\end{array}$ & & & & $\begin{array}{l}.848^{*} \\
(.377)\end{array}$ & $\begin{array}{c}.966 \\
(.572)\end{array}$ \\
\hline Log of freight transport & & $\begin{array}{r}-.174 \\
(.374)\end{array}$ & & & $\begin{array}{r}-.029 \\
(.457)\end{array}$ & $\begin{array}{r}-.103 \\
(.591)\end{array}$ \\
\hline Log cars per capita & & & $\begin{array}{r}-1.687 \\
(1.067)\end{array}$ & & $\begin{array}{r}-2.645^{*} \\
(1.271)\end{array}$ & $\begin{array}{r}-1.316 \\
(1.003)\end{array}$ \\
\hline Average age of cars & & & & $\begin{array}{c}.495 \\
(.599)\end{array}$ & $\begin{array}{c}.328 \\
(.711)\end{array}$ & $\begin{array}{r}-.035 \\
(.499)\end{array}$ \\
\hline adj. $R^{2}$ & .600 & .600 & .601 & .600 & .601 & .548 \\
\hline$N$ & 1560 & 1560 & 1560 & 1560 & 1560 & 840 \\
\hline
\end{tabular}

Notes: The outcome variable is the log of fatalities per $10^{6}$ cars. Specification (6) is run on a sample without the distant regions of Austria and Germany. All specifications include region dummies and an unrestricted set of month $\times$ year effects. Huber-White standard errors clustered on regions are in parentheses: ${ }^{*} p<0.01$.

Sources: Headquarters of the Police of the Czech Republic, Statistics Austria, Federal Statistical Office Germany, and Eurostat.

kilometers driven by trucks and lorries. The increase in freight transport after May 2004 when the Czech Republic became a member of the EU, ${ }^{32}$ was often criticized by media and politicians as adversely affecting the safety of Czech roads. Also, the number of cars per capita grew faster in the Czech Republic than in Austria and Germany. This may negatively influence the number of fatalities per car, because the number of passengers sitting in a car may decrease (see Table 1) and the new cars may be safer. Lastly the age of cars may capture changes in the composition of the quality of cars. The signs of coefficient estimates are as expected, except freight transport does not seem to positively affect fatalities, but none of these variables is statistically significant on its own. Importantly, the initial effects of the new traffic law remain highly statistically significant and substantively large in all four cases, also coefficients for the second to fourth post-reform quarters are quite stable, but never significant. However, the estimated effects beyond the first year are somewhat

\footnotetext{
${ }^{32}$ It did so on May 1, 2004.
} 
unsteady.

In specifications (5) and (6) I include all control variables simultaneously, whereas specification (6) is run on the restricted sample. Coefficients on control variables generally have the same signs and magnitudes across all six specifications. Notably the effects estimated in these last two models are virtually the same as in corresponding specifications (4) and (5) in Table 2. The base results are corroborated by the results in Table (6).

In summary, our results show that there were substantial short-run effects concentrated within the first quarter after the law became effective. This is consistent with the findings of previous studies in other countries (see Table A.1 for a summary of these papers). Although the point estimates are mostly negative, the estimated effects fade as we move away from July 2006. The estimates of long-run effects, that is beyond the first 12 post-reform months, are substantively and statistically insignificant.

\subsection{Short-Run Development}

The availability of daily country-level data on RTA-related fatalities in Austria and the Czech Republic makes it possible to study the response tho the new law in more detail. To inspect the reaction of fatalities to the traffic law reform, I first index daily fatalities by the change in the number of cars and standardize their values by demeaning and dividing by respective standard deviations of each country. ${ }^{33}$ Then I run a regression of normalized fatalities on a constant, a dummy for the Czech Republic, a full set of week effects, and full set of interactions between the dummy for the Czech Republic and week effects using daily data ranging from 2005 to $2008 .^{34}$

\footnotetext{
${ }^{33}$ Note that daily fatalities are small numbers, often taking the value of zero, and there is higher variability of fatalities in the Czech Republic relative to Austria. The results do not depend on the standardization, however.

${ }^{34}$ I tested the equality of pre-July 2006 development in daily fatalities between Austria and the Czech Republic with results far from any rejection criteria. Pearson's correlation coefficient of pre-July 2006 weekly fatalities in the two countries is 0.43 and is highly statistically significant.
} 
Figure 3: Weekly effects of the new traffic law on standardized fatalities (6 months before-12 months after)

A: Week $\times$ Czech Republic dummies, controlling for all week effects.

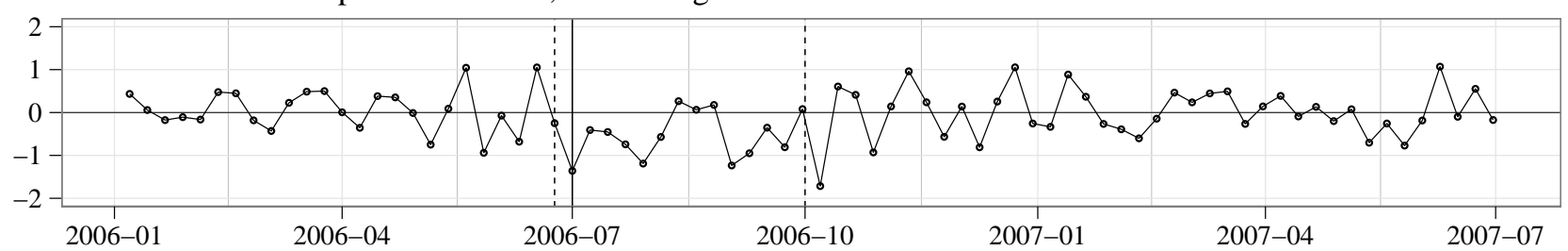

B: Week $\times$ Czech Republic dummies, controlling for common trend and week-of-the-year effects.

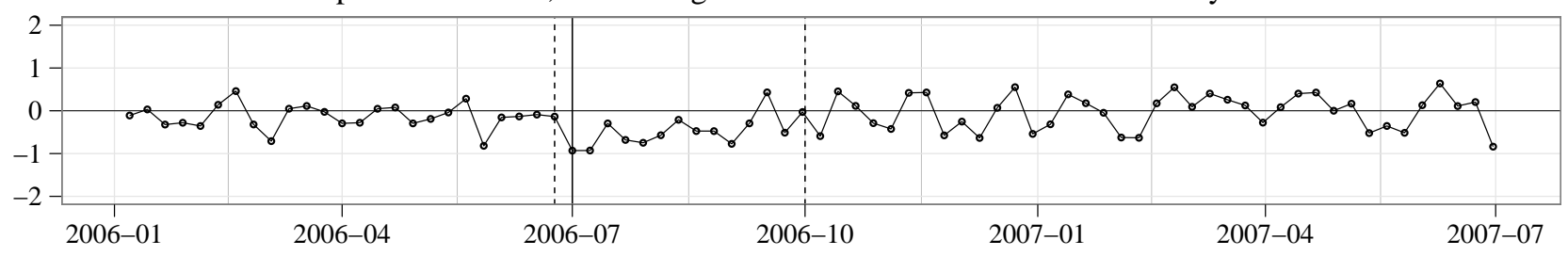

Panel A of Figure 3 plots the demeaned coefficients on the interactions capturing the average weekly change in Czech fatalities net of common shocks. ${ }^{35}$ To improve the readability of the figure, it shows only coefficients for an 18-month window around the reform. The first day of the reform, July 1, 2006, is marked by a solid vertical line, and dashed lines mark one week before and three months after the date. There is no apparent positive or negative trend during the pre-reform period, which is reassuring. Neither are there signs of pre-reform effects. On the contrary, the plot suggests that the law saw its first effects in the very first week it was enforceable. Importantly, the figure corroborates our main finding that the effects of the law were concentrated in the first three months, as most of the estimates for that period lie below the zero line. Specifically, Panel A suggests that the bulk of the decline in fatalities was concentrated in July and October, the first and third post-reform month. Fatalities seem to revert to their pre-reform levels soon after this initial shock.

As an alternative specification, I run a regression of normalized daily fatalities on a constant, a dummy for the Czech Republic, a full set of week-of-the-year effects, a third-degree-polynomial trend, and interactions between the dummy for the Czech Republic and week effects spanning from six months before to 12 months after the

\footnotetext{
${ }^{35}$ More precisely, these are the sums of the coefficients on interactions and the coefficient on the dummy for the Czech Republic.
} 
reform. ${ }^{36}$ The estimated coefficients on the interaction terms are plotted in Panel B of Figure 3. Estimates are less erratic compared to Panel A, as the restrictive model is likely to filter out some noise. The main difference between the two plots is that the rebound seems to be more gradual in Panel B. Otherwise, the interpretation of both figures is remarkably similar. Daily data thus corroborate our main finding of substantial immediate effects of the traffic law reform in the Czech Republic and subsequent rebound toward pre-reform levels.

\section{$5 \quad$ Why Were the Effects Shortlived?}

\subsection{Competing Explanations and Some Theory}

The short life of the initial effects of the traffic law reform is not too surprising. As discussed in the Introduction, this development is consistent with earlier experiences in other countries. ${ }^{37}$ It, however, is a puzzle, and the empirical literature so far has not provided much insight into what causes such effects to be shortlived. I suspect two major factors: expectations and enforcement.

A radical change in traffic law may be ex ante ambiguous with respect to its effects on expected punishment, to which people may overreact, choosing a pessimistic scenario and be overly alert (Alary, Gollier, and Treich 2012). ${ }^{38}$ Then, as the ambiguity resolves, and people adjust their priors accordingly, their care is relaxed. In addition, the politicians - both those who are for the reform as well as those who are against it - the police, and the media may have a tendency exaggerate the magnitude of the expected effects. ${ }^{39}$ Also, people may expect, that tougher punishments generate more incentives for the police to enforce the traffic law.

However, economic theory suggests the opposite - enforcement levels may have

\footnotetext{
${ }^{36}$ Results are the same for linear or quadratic trends.

${ }^{37}$ See also Table A.1.

${ }^{38} \mathrm{It}$ is generally better to be pessimistic in face of ambiguity, because - ex post - one will either have been right, or he will be positively surprised.

${ }^{39}$ The Czech traffic law reform became enforceable during the holiday season, usually characterised by few events in politics, so it may have received even more media attention than otherwise.
} 
gone down in the aftermath of the reform. Intuitively, as higher punishments improve drivers' behavior, enforcement resources may be reallocated to more valuable uses. Tsebelis (1989) was the first to study the relationship between the fine and the effort chosen by the enforcement body. He discusses a succinct game-theoretical model producing a counter-intuitive prediction: a change in the fine does not influence the number of committed infractions, only the probability of capture. ${ }^{40}$

In an earlier version of this paper,${ }^{41}$ I have developed a simple model grasping this scenario in a standard constrained optimization setting. I begin with a straightforward deterrence model, drivers choose the number of offenses given a monetary constraint. The cost of an offense is a fine multiplied by the probability that the offender will be intercepted by the police. In the next step, the police is allowed to optimize their effort, directly influencing the probability of interception and through it the number of offenses the drivers choose to commit. The police dislikes offenses as well as effort. The model predicts that the direct deterrence effect of a higher fine is followed by relaxed enforcement, which in equilibrium offsets some of the former.

There are various reasons why this simple model may capture some of the reality. Resources allocated to traffic police have alternative uses, within the police and within the public sector in general. It is also plausible that when similar large-scale changes in the law are adopted, the traffic police may already be overstretched. If added deterrence resulting from increased punishments leads to an improvement in road-safety indicators, the levels of enforcement may then be adjusted downward. This may be an improvement from the social perspective. Finally, politicians may lose interest in traffic safety, especially if things improve initially. If they later revert, there may not be much to be done for them as the law has been passed already.

\subsection{The Data on Police Activity}

This subsection presents an analysis of a unique dataset parsed from internal monthly regional-level information on traffic police activity in 2006 and 2007 I have obtained

\footnotetext{
${ }^{40}$ See also Holler (1993) and Andreozzi (2002) for a further discussion of Tsebelis' model.

${ }^{41} \mathrm{It}$ is available online at http://ssrn.com/abstract=1595882 or upon request from the author.
} 
Figure 4: Traffic police manpower and man-hours in enforcement by Czech regions in 2006 and 2007

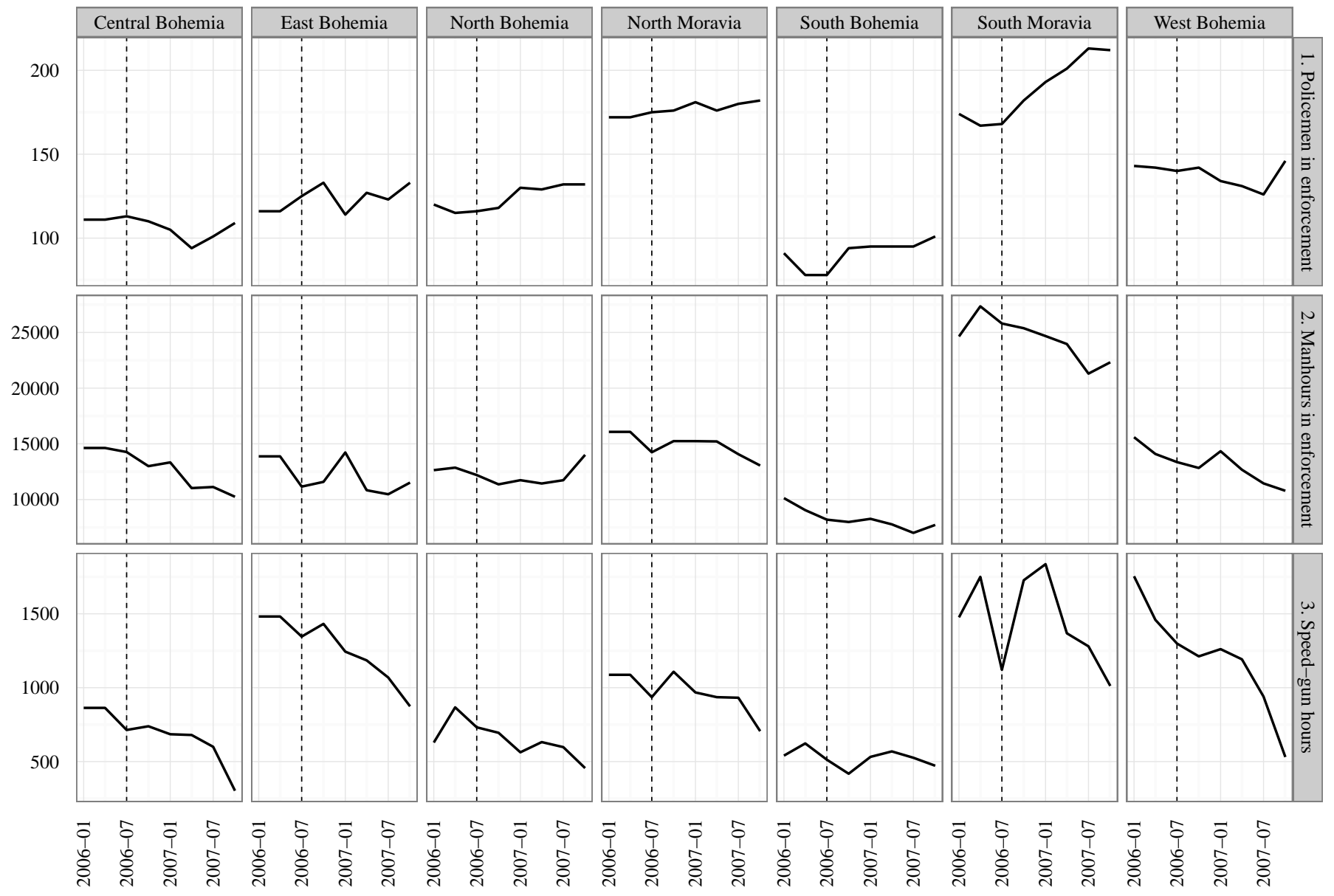

from the Czech Traffic Police Headquarters. The original source of the information are the local police directorates, who report to the Headquarters.

The thrust of the of the findings is captured in Figure 4, which plots the development of manpower and man-hours in enforcement as well as the number of hours of speed gun use by the traffic police across Czech regions. The number of policemen assigned to enforcement a exhibits general upward pattern over 2006 and 2007. Despite that, the man-hours worked by traffic policemen were declining in all regions but one. The number of hours the police spent behind speed guns was falling even more rapidly. ${ }^{42}$

\footnotetext{
${ }^{42}$ Certainly the enforcement infrastructure was improving in recent years. Many static cameras were put in place, so that drivers' speed may be measured with higher frequency. However, speeding captured by static radars gets recorded, and only a subset proceeds through the administrative procedure and possibly results in punishment of the driver, with a delay.
} 


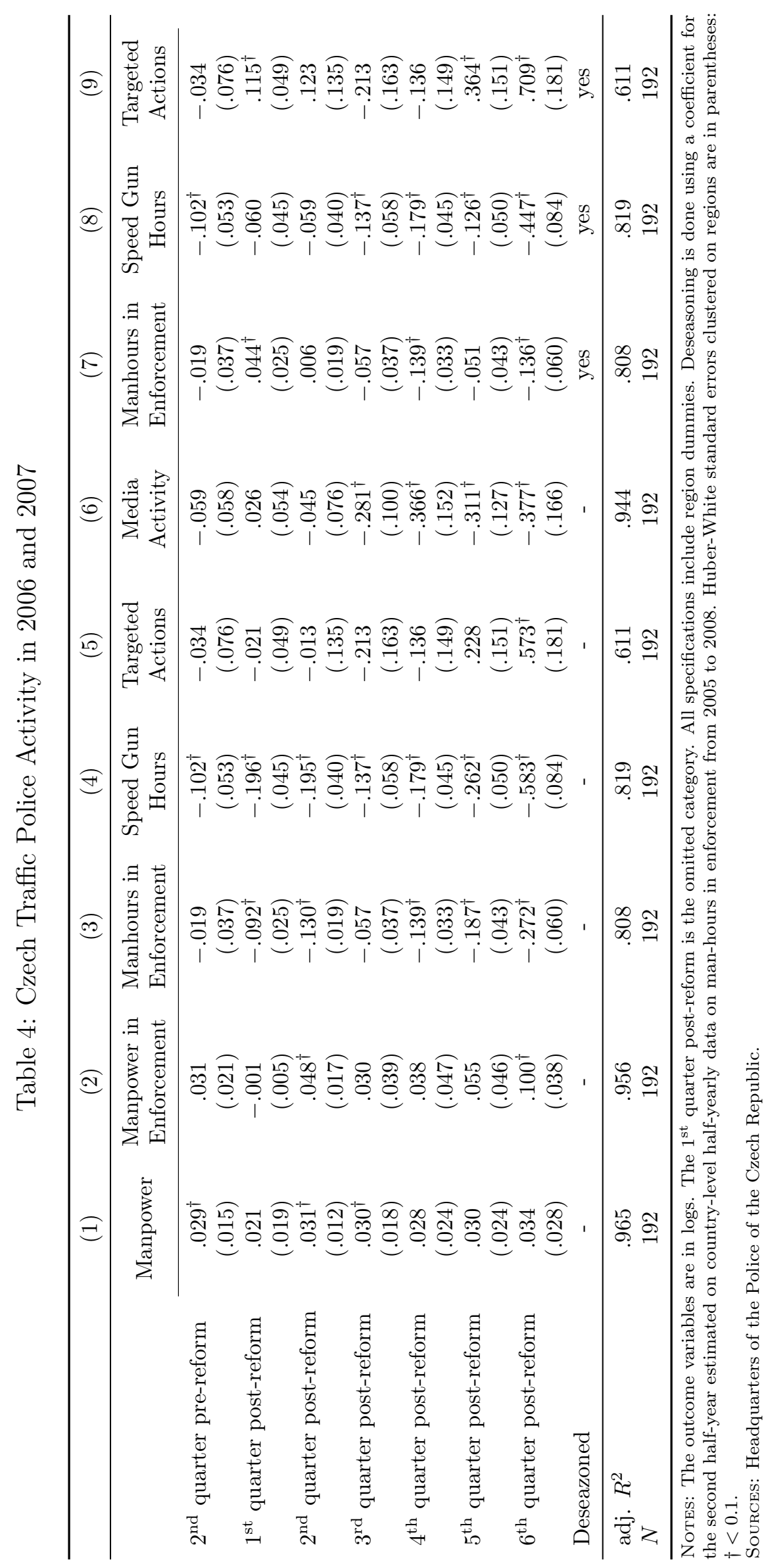


Tables 4 and 5 study traffic police activity in more detail. I simply regress the logs of police activity indicators on year $\times$ quarter dummies, where the second quarter of 2006 is the omitted category. One may worry that some variability may be driven by seasonal regularities, an issue hard to deal with properly with two years of data. I use half-yearly country-level data on man-hours in enforcement ranging from 2005 to 2008 and estimate a coefficient for a second half-year, which I then use to deseason the monthly data on police activity.

Column (1) of Table 4 suggests that the total number of policemen remained constant throughout 2006 and 2007, while the number of policemen in enforcement was slowly increasing as seen in column (2) and Figure 4. In other words, there is no sign that fewer policemen were available for traffic law enforcement after June $2006 .{ }^{43}$ Nonetheless, the total amount of traffic police man-hours dedicated to enforcement was gradually declining from the third quarter of 2006 onwards. The declines are statistically significant at 5 the percent level and the pace was accelerating. Since man-hours in enforcement are usually smaller in the second half of the year (although fatalities are higher), the results for deseasoned data places the beginning of the decline to the first quarter of 2007. Nonetheless, there were almost $9 \%$ fewer traffic policemen seen on the streets and roads in the first quarter following the introduction of the new traffic law compared to the preceding one, and the decline came close to $24 \%$ by the end of 2007 . The decay is even more dramatic in the case of speed gun hours by the traffic police. The number of targeted actions - that is the temporarily increased presence of traffic police in a specific area with the purpose to increase the number of checks and the salience of police presence - remained steady through 2006, then declined in the first half of 2007 and later increased substantially. The presence of the police in the media decreased in 2007, as it was probably unusually high in 2006.

Table 5 looks at activities of the traffic police other than direct traffic law enforcement. Specifically, I looked at the numbers of persons and cars at large

\footnotetext{
${ }^{43}$ Also, as noted in Section 2, the municipal police was newly authorized to stop vehicles and fine offenders.
} 


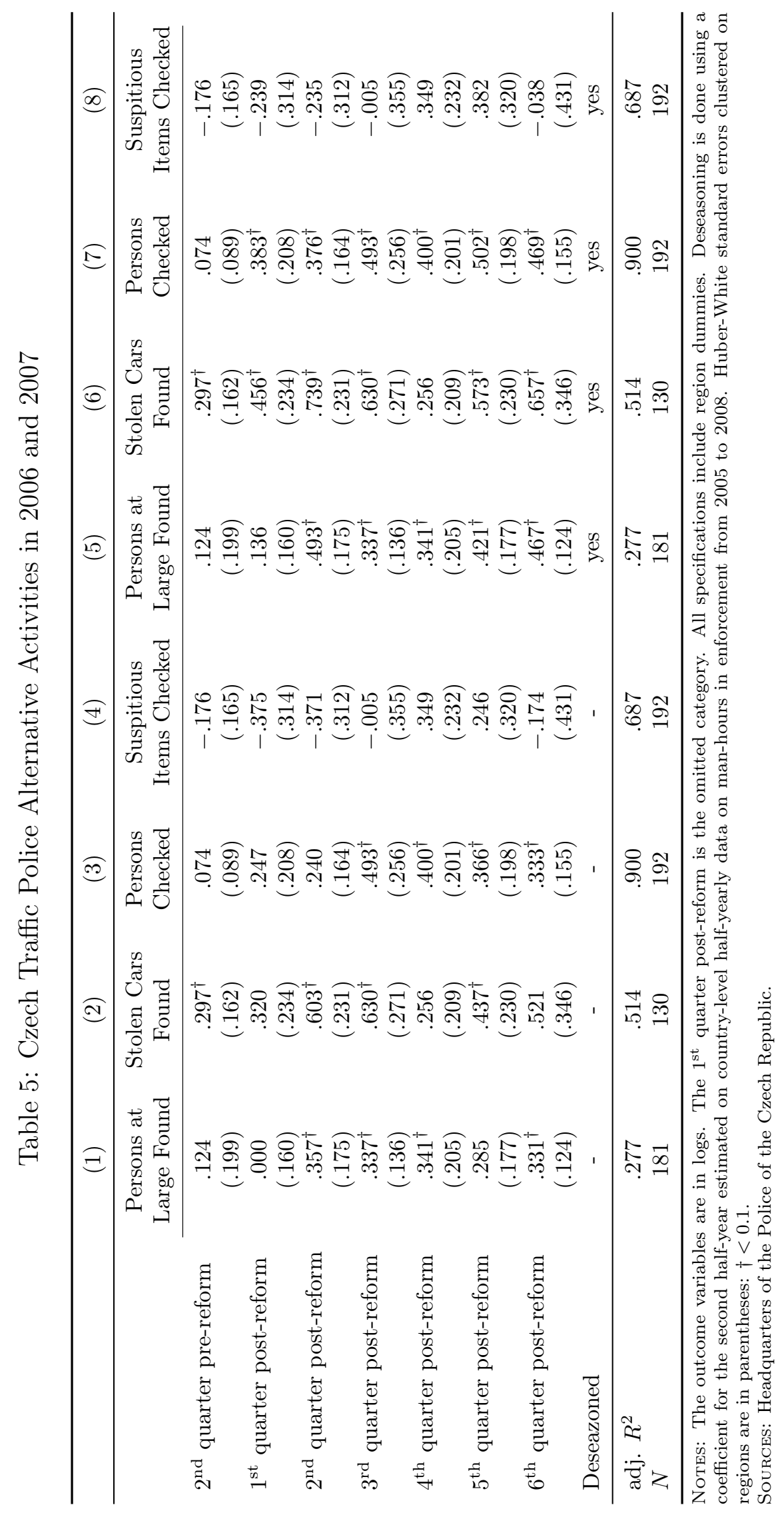


found, and the numbers of suspicious items and persons checked. Although most coefficients are not statistically significant, there seems to be a general increase in these measures, despite fewer working hours in enforcement. This suggests that the traffic police may have given higher priority to general law enforcement activities relative to pure enforcement of traffic rules.

\subsection{What Does (Not) the Traffic Police Activity Explain?}

In sum, the police data reveal that enforcement levels were declining in the aftermath of the traffic law reform and suggest that traffic police may have put a higher share of resources into general law enforcement and police work and away from the direct enforcement of traffic rules. This development is in line with the outlined theory, however one should be careful before interpreting this result strictly causally. Only two years of data are available, so we cannot rule out preexisting trends or factors driving the changes in police data other than the change in the traffic law. ${ }^{44}$

Be it coincidence or not, can changes in police enforcement explain the development of fatalities after the change in Czech road traffic law? It can hardly do so with respect to the sharp short-run decline in fatalities as the police presence on the roads was apparently lower during the third quarter of 2006, relative to first half of that year. This effect is more likely to be driven by uncertainty in expectations that were possibly misjudged due to the high salience of the change as well as the intense media coverage and long-lasting controversies regarding the DPS. On the other hand, systematically lower enforcement levels after the law was introduced may play a role in explaining the absence of long-run effects.

\footnotetext{
${ }^{44} \mathrm{~A}$ note of caution should be stated here: One could be tempted to use the data on traffic police activity as an explanatory variable to check whether it explains the development in fatalities in the Czech Republic after July 1, 2006. However, this would require that traffic police activity is exogenous to accidents and casualties - an unlikely assumption. Doing this would lead to results lacking proper interpretation. I therefore present only a descriptive analysis of police activity.
} 


\section{Conclusions}

This study evaluates the effects of the introduction of a new road traffic law on RTA-related fatalities in the Czech Republic. The law became effective on July 1, 2006 and introduced a number of provisions that increased sanctions for traffic offenses. In particular, fines increased substantially, the traffic police gained more authority, and a strict demerit point system was introduced. The law was long disputed as the severity of the increase in punishment was controversial; the main object of controversy was the demerit point system. Yet the reform also had strong supporters, notably the police, as it was expected to bring a major improvement in drivers' behavior and road traffic safety.

Consistent with the literature, studying the effects of similar changes in traffic laws in other countries, I find a substantial initial response to the increase in punishments for traffic offenses. Fatalities were about one-third lower during the first three months after the law was introduced. From 51 to 204 - with point estimate of 119 - human lives were saved with 95 percent certainty in that period. The estimate for the 12 post-reform months is 193 lives saved. However, the estimated effects after the initial three-month period are generally negative and substantively moderate, but never statistically significant. The point estimates of the effects going beyond the first 12 months are close to zero, although moderate positive or negative effects cannot be ruled out. These findings hold across various specifications and are robust to controlling for the number of cars per inhabitant, GDP per capita, age of cars, and intensity of freight transport.

This study extends the set of studies that find strong immediate but little, if any, sustained effects of tougher punishments for traffic law violations. Because the expected punishment is what drivers should care about, the key issue is the development of police resources and effort devoted to the enforcement of the law. I study a unique detailed dataset parsed from internal reports that regional traffic police offices provide to the Czech traffic police headquarters. The data reveals that resources allocated to enforcement were decaying, namely man-hours and the 
intensity of the use of speed guns. There are also indications that traffic police may have shifted attention towards ancillary activities and more general law enforcement. It is noteworthy in this context that traffic intensity, measured by number of cars, kilometers driven, or intensity of freight transport, was increasing substantially during the period under study. Traffic-intensity-adjusted enforcement levels may have decayed even faster.

A continuous decline in traffic law enforcement cannot, however, explain the short-run pattern of the reaction to the legal reform. It is plausible to hypothesize that people overestimated the effects of the law on expected punishment, which were ambiguous in the first place. This may have led them to be overly careful during first post-reform weeks. As the uncertainty resolved, people corrected their priors and fatalities rebounded. A proper evaluation of the importance of this mechanism is a task for future research.

The paper does not imply that the law was not an improvement. To the contrary, it created a legal environment that is closer to the standards found in the rest of Europe. By introducing the demerit point system, sanctions became more independent of income (at least formally), thus providing added deterrence and incapacitation of drivers that may not perceive fines as biting enough - there were as many as 34,000 drivers whose driver's licenses were revoked through DPS as of December 2011. Nevertheless, the effective sanctions that offenders care about are a function of enforcement. The expectation that a nominal increase in penalties fix the problem may take enforcement out of the focus and the police and/or politicians may have incentives to reduce enforcement, especially if things seem to go well initially. This this is consistent with the data on police activity and may help explain the absence of any long-run effects. 


\section{References}

Alary, David, Christian Gollier, and Nicolas Treich. 2012. "The Effect of Ambiguity Aversion on Insurance Demand." Unpublished Manuscript, Toulouse School of Economics.

Andreozzi, Luciano. 2002. "Oscilliations in the Enforcement of Law: An Evolutionary Analysis." Homo Oeconomicus 18:403-428.

Basili, Marcello, Filippo Belloc, Simona Benedettini, and Antonio Nicita. 2012. "Warning, Learning and Compliance: Evidence from Micro-data on Driving Behavior." Working Paper no. 639, Department of Economics, University of Siena.

Benedettini, Simona, and Antonio Nicita. 2009. "Rational Drivers, Irrational Enforcers, and Road Safety." Unpublished Manuscript, University of Siena.

Butler, J. S., J. P. Burke, D. G. Healy, M. M. Stephens, F. McManus, D. McCormack, J. M. O'Byrne, and A. R. Poynton. 2006. "Trends in RTA Related Spinal Injuries: The Post Penalty Points Era." Irish Journal of Medical Science 175 (1): $20-23$.

Chipman, M. L., and Peter Morgan. 1975. "The Role of Driver Demerit Points and Age in the Prediction of Motor Vehicle Collisions." British Journal of Preventive and Social Medicine 29 (3): 190-195.

Farchi, Sara, Francesco Chini, Paolo Giorgi Rossi, Laura Camilloni, Piero Borgia, and Gabriella Guasticchi. 2007. "Evaluation of the Health Effects of the New Driving Penalty Point System in the Lazio Region, Italy, 2001-4." Injury Prevention 13 (1): 60-64.

Friedman, Milton. 1992. "Do Old Fallacies Ever Die?" Journal of Economic Literature 30 (4): 2129-2132.

Healy, D. G., P. Connolly, M. M. Stephens, J. M. O’Byrne, F. McManus, and D. McCormack. 2004. "Speed and Spinal Injuries." Injury 35 (9): 908-912. 
Holler, Manfred J. 1993. "Fighting Pollution When Decisions Are Strategic." Public Choice 76 (4): 347-356.

Hussain, O. T., M. S. Nayyar, F. A. Brady, J. C. Beirne, and L. F. A. Stassen. 2006. "Speeding and Maxillofacial Injuries: Impact of the Introduction of Penalty Points for Speeding Offences." British Journal of Oral and Maxillofacial Surgery 44 (1): 15-19.

Instituto Nazionale di Statistica. 2005. "Statistica degli incidenti stradali, Anni 2003-2004." Technical Report, Instituto Nazionale di Statistica, Italy.

Levitt, Steven D., and Jack Porter. 2001. "How Dangerous Are Drinking Drivers?" Journal of Political Economy 109 (6): 1198-1237.

Mehmood, Arif. 2010. "Evaluating Impact of Demerit Points System on Speeding Behavior of Drivers." European Transport Research Review 2 (1): 25-30.

Parliamant of the Czech Republic. 2005. ZÁKON ze dne 21. zář́i 2005, kterým se mění zákon č. 361/2000 Sb., o provozu na pozemních komunikacích a o změnách některých zákonů, ve znění pozdějších předpisů, zákon č. 200/1990 Sb., o přestupcích, ve znění pozdějších předpisů, zákon č. 247/2000 Sb., o získávání a zdokonalování odborné způsobilosti k řízení motorových vozidel a o změnách některých zákonů, ve znění pozdějších předpisů, a některé další zákony.

Redelmeier, Donald A., Robert J. Tibshirani, and Leonard Evans. 2003. "Traffic-Law Enforcement and Risk of Death from Motor-Vehicle Crashes: Case-Crossover Study." Lancet 361 (9376): 2177-2182.

Tsebelis, George. 1989. "The Abuse of Probability in Political Analysis: The Robinson Crusoe Fallacy." American Political Science Review 83 (1): 77-91.

World Health Organization. 2009. "Global Status Report on Road Safety: Time for Action." Technical Report, World Health Organization, Geneva.

Zambon, Francesco, Ugo Fedeli, Giovanni Milan, Stefano Brocco, Maria Marchesan, Sandro Cinquetti, and Paolo Spolaore. 2008. "Sustainability of the Effects of 
the Demerit Points System on Seat Belt Use: A Region-Wide Before-and-After Observational Study in Italy." Accident Analysis \& Prevention 40 (1): 231-237. Zambon, Francesco, Ugo Fedeli, Cristiana Visentin, Maria Marchesan, Francesco Avossa, Stefano Brocco, and Paolo Spolaore. 2007. "Evidence-Based Policy on Road Safety: The Effect of the Demerit Points System on Seat Belt Use And Health Outcomes." Journal of Epidemiology and Community Health 61 (10): $877-881$. 
Appendix 


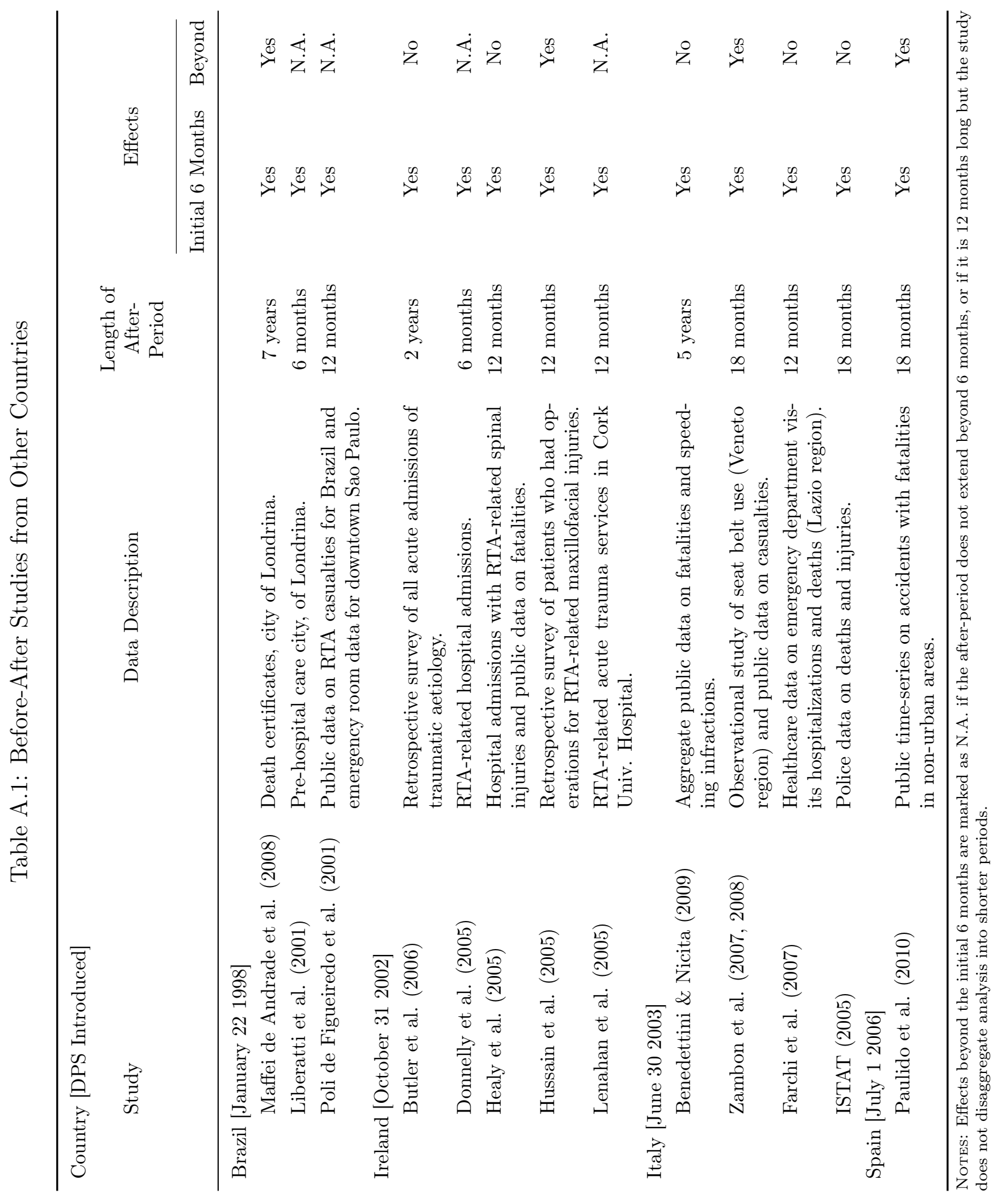


Table A.2: Overview of Novel Provisions in the 2006 Traffic Law

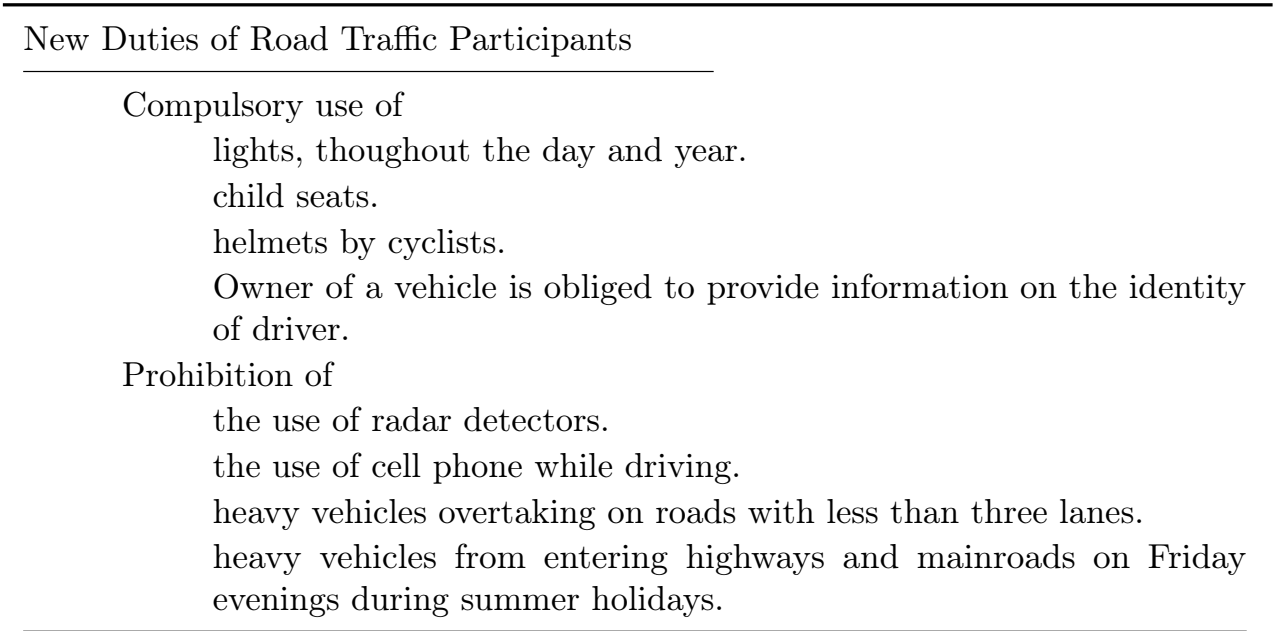

New Police Powers

Police can

withdraw a driver's licence on the spot. Final revocation decision is made by a municipal authority whithin 5 days.

seize a vehicle to prevent the driver from driving.

prevent driver from driving if he refuses an alcohol or drug test test. require a bail security if driver is suspected of avoiding authorities.

Municipal police can measure speed, stop drivers, impose fines, and require an alcohol test.

New Prison Sanctions

Driving while heavily drunk can be qualified as crime with up to one year imprisonment.

The maximum sentence for driving while heavily drunk raises from one to three years in cases of repeated offenders, public transport drivers, or in case of an accident. 
Table A.3: Summary of Transport and Economic Statistics (Means of 2004/2005 and $2007 / 2008)$

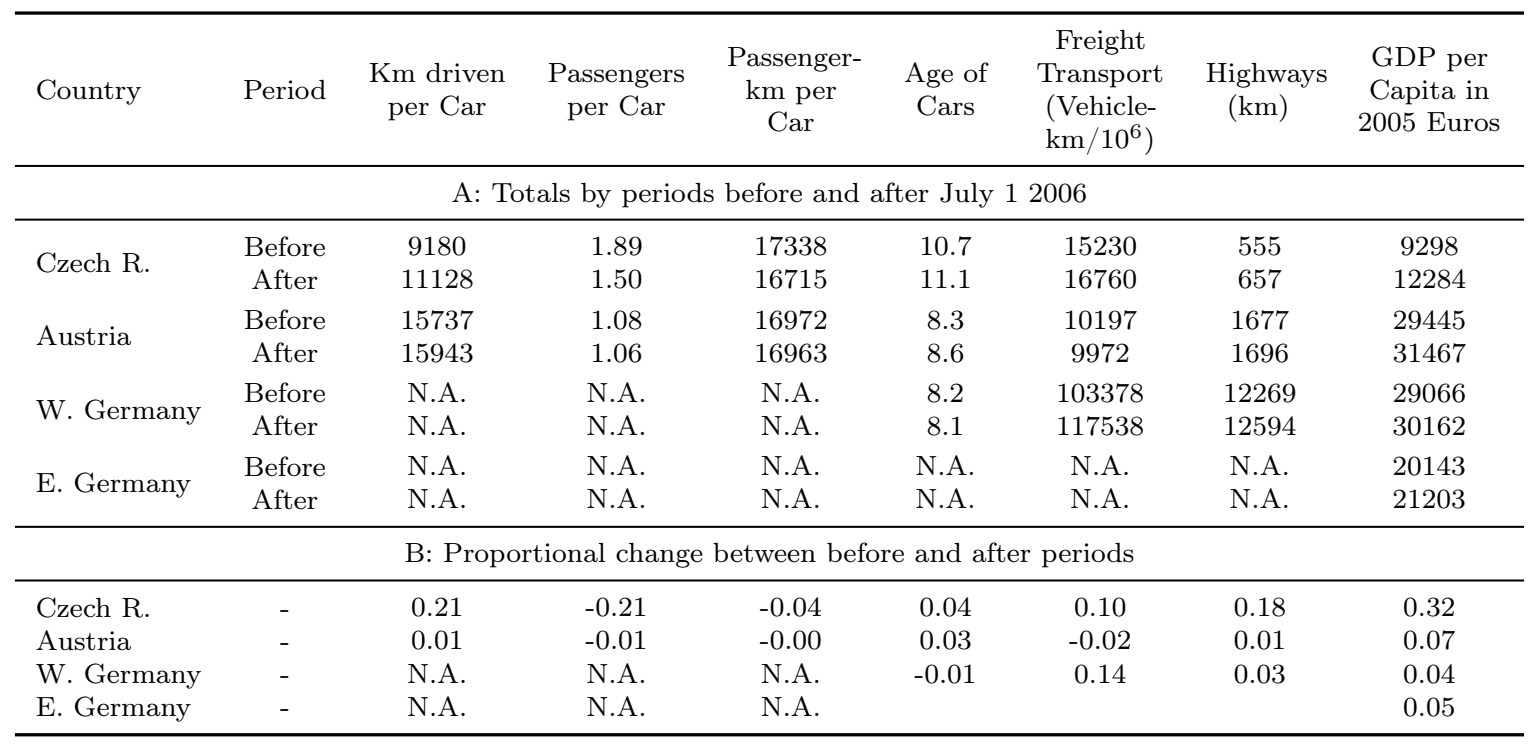

Notes: The values of the age of cars, freight transport, and highways refer to all of Germany.

SOurCes: Eurostat. 


\section{Working Paper Series}

ISSN 1211-3298

Registration No. (Ministry of Culture): E 19443

Individual researchers, as well as the on-line and printed versions of the CERGE-EI Working Papers (including their dissemination) were supported from institutional support RVO 67985998 from Economics Institute of the ASCR, v. v. i.

Specific research support and/or other grants the researchers/publications benefited from are acknowledged at the beginning of the Paper.

(c) Josef Montag, 2013

All rights reserved. No part of this publication may be reproduced, stored in a retrieval system or transmitted in any form or by any means, electronic, mechanical or photocopying, recording, or otherwise without the prior permission of the publisher.

Published by

Charles University in Prague, Center for Economic Research and Graduate Education (CERGE) and

Economics Institute ASCR, v. v. i. (EI)

CERGE-EI, Politických vězňů 7, 11121 Prague 1, tel.: +420 224005 153, Czech Republic.

Printed by CERGE-EI, Prague

Subscription: CERGE-EI homepage: http://www.cerge-ei.cz

Phone: + 420224005153

Email: office@cerge-ei.cz

Web: http://www.cerge-ei.cz

Editor: Michal Kejak

The paper is available online at http://www.cerge-ei.cz/publications/working_papers/.

ISBN 978-80-7343-288-1 (Univerzita Karlova. Centrum pro ekonomický výzkum a doktorské studium)

ISBN 978-80-7344-280-4 (Národohospodářský ústav AV ČR, v. v. i.) 
CERGE-EI

P.O.BOX 882

Politických vězňů 7

11121 Praha 1

Czech Republic http://www.cerge-ei.cz 